Article

\title{
Epoxyscillirosidine Induced Cytotoxicity and Ultrastructural Changes in a Rat Embryonic Cardiomyocyte (H9c2) Cell Line
}

\author{
Hamza Ibrahim Isa ${ }^{1,2}, *$, Gezina Catharina Helena Ferreira ${ }^{1}$, Jan Ernst Crafford ${ }^{3}$ and \\ Christoffel Jacobus Botha ${ }^{1}$ (D) \\ 1 Department of Paraclinical Sciences, University of Pretoria, Onderstepoort 0110, Gauteng, South Africa; \\ arina.ferreira@up.ac.za (G.C.H.F.); christo.botha@up.ac.za (C.J.B.) \\ 2 Department of Veterinary Pharmacology and Toxicology, Ahmadu Bello University, Zaria 810107, Nigeria \\ 3 Department of Veterinary Tropical Diseases, University of Pretoria, Onderstepoort 0110, Gauteng, South Africa; \\ jannie.crafford@up.ac.za \\ * Correspondence: hiisah@abu.edu.ng
}

Received: 18 April 2019; Accepted: 5 May 2019; Published: 21 May 2019

check for updates

\begin{abstract}
Moraea pallida Bak. (yellow tulp) poisoning is the most important cardiac glycoside-induced intoxication in ruminants in South Africa. The toxic principle, $1 \alpha, 2 \alpha$-epoxyscillirosidine, is a bufadienolide. To replace the use of sentient animals in toxicity testing, the aim of this study was to evaluate the cytotoxic effects of epoxyscillirosidine on rat embryonic cardiomyocytes (H9c2 cell line). This in vitro cell model can then be used in future toxin neutralization or toxico-therapy studies. Cell viability, evaluated with the methyl blue thiazol tetrazolium (MTT) assay, indicated a hormetic dose/concentration response, characterized by a biphasic low dose stimulation and high dose inhibition. Increased cell membrane permeability and leakage, as expected with necrotic cells, were demonstrated with the lactate dehydrogenase $(\mathrm{LDH})$ assay. The $\mathrm{LC}_{50}$ was $382.68,132.28$ and $289.23 \mu \mathrm{M}$ for 24,48 , and $72 \mathrm{~h}$ respectively. Numerous cytoplasmic vacuoles, karyolysis and damage to the cell membrane, indicative of necrosis, were observed at higher doses. Ultra-structural changes suggested that the cause of $\mathrm{H} 9 \mathrm{c} 2$ cell death, subsequent to epoxyscillirosidine exposure, is necrosis, which is consistent with myocardial necrosis observed at necropsy. Based on the toxicity observed, and supported by ultra-structural findings, the H9c2 cell line could be a suitable in vitro model to evaluate epoxyscillirosidine neutralization or other therapeutic interventions in the future.
\end{abstract}

Keywords: Cardiac glycoside; epoxyscillirosidine; H9c2 cells; hormesis; LDH assay; Moraea pallida; MTT assay; necrosis; poisoning

Key Contribution: Using the LDH assay and further confirmed with transmission electron microscopy (TEM); it is concluded that the cytotoxic effect of epoxyscillirosidine in H9c2 cells is necrosis. The H9c2 cell line could be a suitable in vitro model to investigate aspects of Moraea pallida (yellow tulp) poisoning in livestock and to reduce the use of live; sentient animals in experimentation.

\section{Introduction}

Moraea pallida Bak. (yellow tulp) poisoning in livestock is the most important of all cardiac glycoside-associated plant poisonings in the Republic of South Africa. Acute poisoning with severe cardiac rhythm aberrations occurs, and the mortality rate is high. Yellow tulp poisoning together with other cardiac glycoside toxicoses accounts for about $33 \%$ and $10 \%$ mortality, due to plant poisonings in cattle, and small stock, respectively [1]. In poisoned animals the respiratory, cardiovascular, gastrointestinal, and nervous systems are involved, and signs may include general apathy, tremors, 
weakness of hindquarters, respiratory distress, and at times bruxism and groaning sounds [2]. Microscopic cardiac lesions are myocardial degeneration and necrosis [3]. The toxic principle is a bufadienolide, $1 \alpha, 2 \alpha$-epoxyscillirosidine [3,4]. The molecular formula of the compound is $\mathrm{C}_{26} \mathrm{H}_{32} \mathrm{O}_{8}$ and is chemically closely related to scillirosidine, contained in Urginea maritima var rubra. Epoxyscillirosidine was identified as being responsible for the intoxication of livestock [4], as well as an aversive compound, causing feed aversion in livestock $[3,5,6]$. Bufadienolides, similar to other cardiac glycosides, interfere with the function of the ubiquitous sodium potassium adenosine triphosphatase $\left(\mathrm{Na}^{+}-\mathrm{K}^{+}\right.$-ATPase) on the cell membrane [7]. The $\mathrm{Na}^{+}-\mathrm{K}^{+}$-ATPase acts as the receptor for cardiac glycosides and structurally similar compounds $[7,8]$.

The H9c2 (2-1) embryonic rat cardiomyocyte cell line is a sub-clone of the original clonal line, which was derived from embryonic BD1X rat cardiac tissue [9]. This cell line has commonly been utilized in cardiotoxicity studies of novel, mainly anticancer drugs, to elucidate mechanisms of cell injury in cardiac cells, and to evaluate apoptotic and necrotic lesions in cardiomyocytes, that are induced by various compounds and toxins [10].

The response of the H9c2 cells, following epoxyscillirosidine exposure, may reveal important clues as to how cardiac cells and the heart are affected in animals poisoned by yellow tulp. In addition, an in vitro tissue culture model can replace the use of sentient animals and circumvent animal ethics concerns in future toxicity studies. The aim of this study was to investigate the effect of epoxyscillirosidine on rat embryonic cardiomyocytes of the H9c2 type by evaluating cell viability, cytotoxicity, as well as characterizing morphological changes induced in exposed cells. Cell viability was evaluated using the methyl blue thiazol tetrazolium (MTT) assay, while cytotoxicity was determined using the lactate dehydrogenase (LDH) release assay. Ultra-structural changes were assessed using transmission electron microscopy (TEM).

\section{Results}

\subsection{Cell Viability}

Cell viability increased when the $\mathrm{H} 9 \mathrm{c} 2$ cells were exposed to epoxyscillirosidine at low doses (10-40, 10 and 10-20 $\mu \mathrm{M}$ ) for 24, 48 and $72 \mathrm{~h}$, respectively. After $24 \mathrm{~h}$, the highest (relative to control) cell viability $(137.68 \pm 7.87 \%)$ was observed following exposure to $10 \mu \mathrm{M}$ and the toxic effect started manifesting at $60 \mu \mathrm{M}(95.62 \pm 15.68 \%$ cell viability). The lowest cell viability $(69.42 \pm 8.95 \%)$ observed was at $160 \mu \mathrm{M}$ (Figure 1 ).

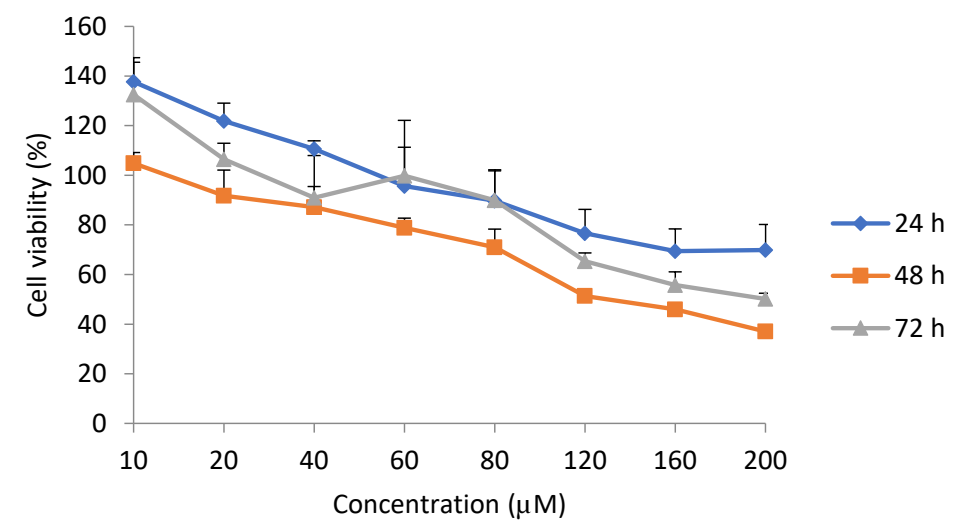

Figure 1. Dose-response curve for viability using methyl blue thiazol tetrazolium (MTT) assay in H9c2 cells exposed to epoxyscillirosidine for 24,48 and $72 \mathrm{~h}$. Cell viability presented as percentage of control $(n=3)$. Each value in the curves represents per-cent viability (mean \pm SD). The Students; $t$-test (unpaired, two tailed) was used to compare the durations of exposure. Cell viability was not significantly $(p>0.05)$ different between any of the durations $(24,48$ and $72 \mathrm{~h})$. The values were the average of three independent experiments. 
After $48 \mathrm{~h}$ exposure, at $10 \mu \mathrm{M}$, cell viability was $104.85 \pm 4.32 \%$. The toxic effects of epoxyscillirosidine were seen at $20 \mu \mathrm{M}$, with cell viability of $91.75 \pm 10.35 \%$ (Figure 1). Cell viability was $37.04 \pm 2.34 \%$ at the highest dose $(200 \mu \mathrm{M})$ evaluated.

After $72 \mathrm{~h}$ incubation at $10 \mu \mathrm{M}$ epoxyscillirosidine the cell viability was $132.52 \pm 14.89 \%$. The toxic effect started manifesting only at $40 \mu \mathrm{M}$, where cell viability decreased to $90.90 \pm 17.06 \%$. At $200 \mu \mathrm{M}$, the cell viability was $50.16 \pm 2.31 \%$ (Figure 1 ).

Overall, cell viability was not significantly $(p>0.05)$ different among the three durations.

\subsection{Median Lethal Concentration}

The median lethal concentration $\left(\mathrm{LC}_{50}\right)$ of epoxyscillirosidine, was extrapolated to be 382.68 , 132.28 and $289.23 \mu \mathrm{M}$ after 24,48 , and $72 \mathrm{~h}$, respectively (Figure 2).
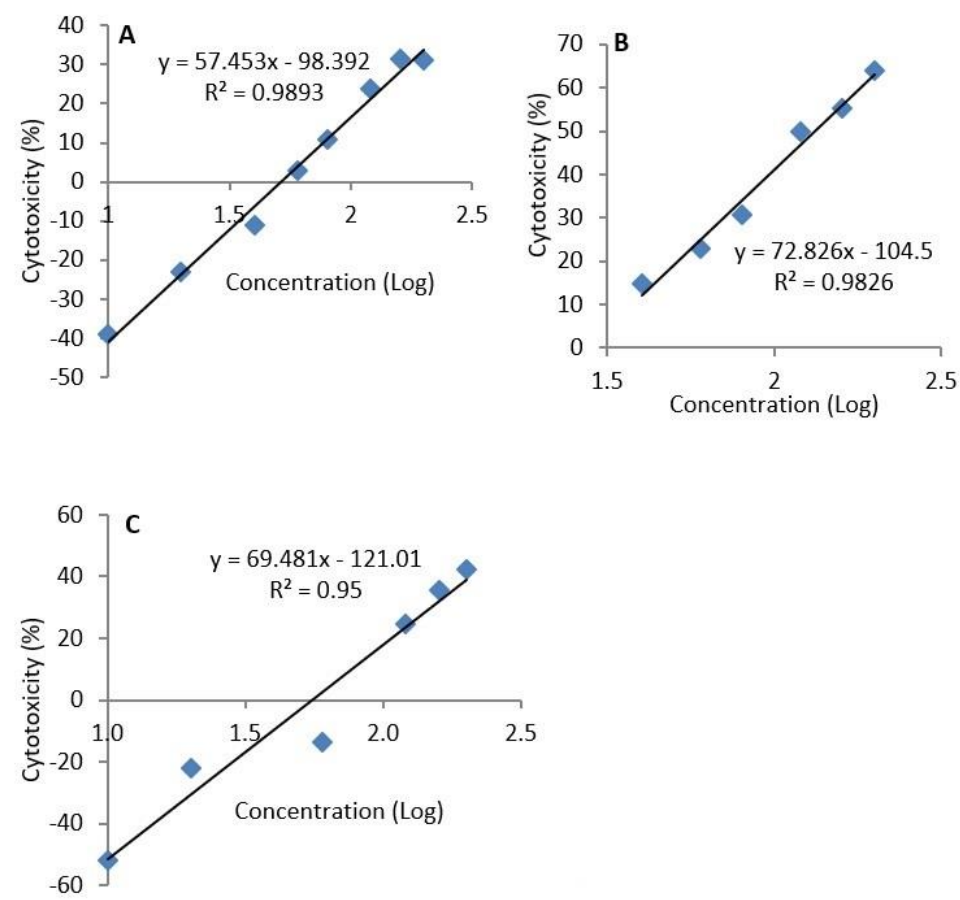

Figure 2. Semi-logarithmic concentration-cytotoxicity plots for $\mathrm{H} 9 \mathrm{c} 2$ cells exposure to epoxyscillirosidine for 24,48 and $72 \mathrm{~h}$ (A-C, respectively). The MTT assay was used to evaluate cytotoxicity. The $\mathrm{LC}_{50}$ was determined by substituting the value for $y$ with 50 in the equation $y=m x+c$. The $\mathrm{LC}_{50}$ is the antilog of the value obtained for $x$. The result represents the means of 3 independent experiments.

\subsection{Cytotoxicity}

The cytotoxicity following exposure to epoxyscillirosidine, as evaluated using the LDH release assay, revealed a dose- and time-dependent effect (Figure 3). Cytotoxicity (expressed as percentage of total lysed cells) increased from $5.69 \pm 1.79 \%$ after $24 \mathrm{~h}$ to $50.73 \pm 16.97 \%$ after $72 \mathrm{~h}$ at the lowest dose $(10 \mu \mathrm{m})$, while it ranged from $40.02 \pm 6.82$ to $78.25 \pm 18.52 \%$ at the highest dose $(200 \mu \mathrm{M})$ evaluated.

Cytotoxicity at the same dose, but at different exposure durations, revealed a time-dependent effect. After $24 \mathrm{~h}$ exposure to epoxyscillirosidine, the lowest percentage cytotoxicity across all the different doses occurred (Figure 3). The $48 \mathrm{~h}$ duration showed lower percentage cytotoxicity when compared with $72 \mathrm{~h}$ at lower doses up to $60 \mu \mathrm{M}$, but the effect was higher from 80-200 $\mu \mathrm{M}$. Cytotoxicity at $72 \mathrm{~h}$ was significantly $(p<0.05)$ different from that at $24 \mathrm{~h}$.

Cytotoxicity, as revealed by the MTT assay, was not significantly $(p>0.05)$ different from the LDH assay at 24 and $48 \mathrm{~h}$. However, there was significant $(p<0.05)$ difference in cytotoxicity revealed by the LDH assay when compared with the MTT assay at $72 \mathrm{~h}$ (Figure 4). 


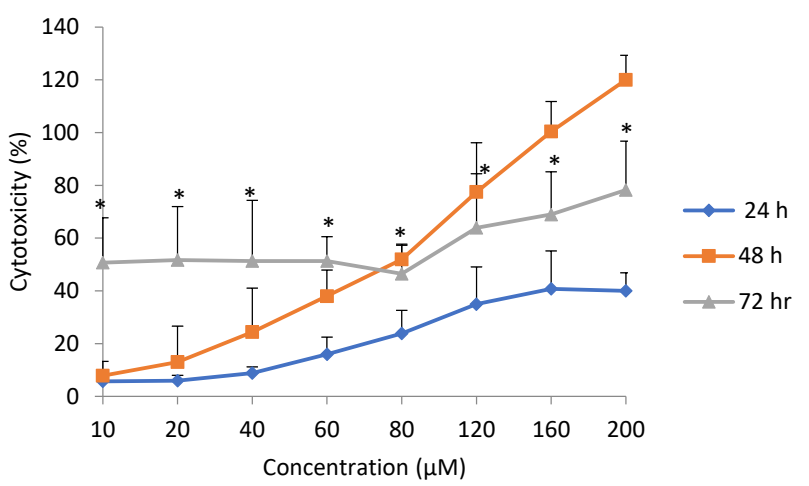

Figure 3. Dose-response curve for cytotoxicity (lactate dehydrogenase (LDH) assay) in H9c2 cells exposed to epoxyscillirosidine for 24,48 and $72 \mathrm{~h}$. Each value in the curve represents cytotoxicity as percentage (mean $\pm \mathrm{SD}$ ). Student's $t$-test (unpaired, two tailed) was used to compare the durations of exposure. ${ }^{*}$ Cytotoxicity at $72 \mathrm{~h}$ was significantly $(p<0.05)$ different from than at $24 \mathrm{~h}$. The values are the result of three independent experiments.
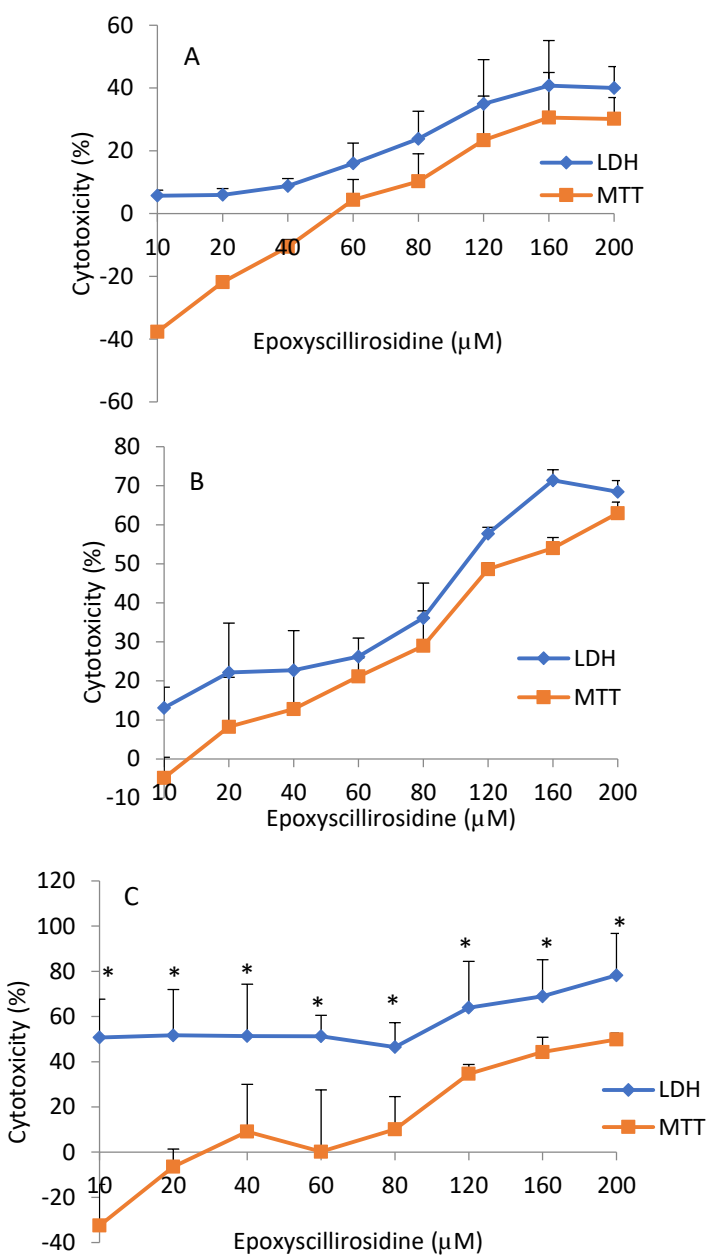

Figure 4. Comparison of the MTT and $\mathrm{LDH}$ dose-response curves of $\mathrm{H} 9 \mathrm{c} 2$ cells exposure to epoxyscillirosidine for 24,48 , and $72 \mathrm{~h}$ (A-C, respectively). The negative MTT values represent a stimulatory effect and cell proliferation at low doses (hormesis). Each value in the curve represents percentage (mean $\pm \mathrm{SD}$ ) cell viability (relative to control). Student's $t$-test was used to analyze the data. Cytotoxicity using LDH compared with MTT assay was significantly ( $\left.{ }^{*} p<0.05\right)$ different at $72 \mathrm{~h}$. There was no difference $(p>0.05)$ in cytotoxicity, as revealed by LDH and MTT assays, at 24 and $48 \mathrm{~h}$. The values are the means of three independent experiments. 
Comparison of cytotoxicity using MTT and LDH assays at the same concentration and duration of exposure indicated that the LDH assay had consistently higher values than the cytotoxicity revealed by the MTT assay. For example, following exposure to $80 \mu \mathrm{M}$ epoxyscillirosidine for $24 \mathrm{~h}$, cytotoxicity was $23.83 \pm 8.78 \%$ and $10.27 \pm 12.48 \%$ with LDH, and MTT assays, respectively (Figure 4). Cytotoxic effect as evaluated with the MTT assay was negative at low doses in all the durations (Figure 4).

\subsection{Changes in Ultra-Structure}

The organelles and cell shape were unaffected in the control cells. Normally, H9c2 myoblasts are spindle-to-stellate-shaped cells that can be mono- or multi-nucleated [10] (Figure 5A). In cells exposed to epoxyscillirosidine over 24,48 , and $72 \mathrm{~h}$, time and dose-dependent morphological alterations were observed. Appearance of cytoplasmic vesicles, vacuoles, changes in nuclear morphology, cytoplasm and damage to the cell membrane in $\mathrm{H} 9 \mathrm{c} 2$ cells, after exposure to epoxyscillirosidine, were evident. These changes only became apparent at higher doses (160-200 $\mu \mathrm{M}$ ) (Figure 5B,C,F). The cells also changed shape from spindle-like to spherical at higher concentrations (Figure 5B,C,E,F).
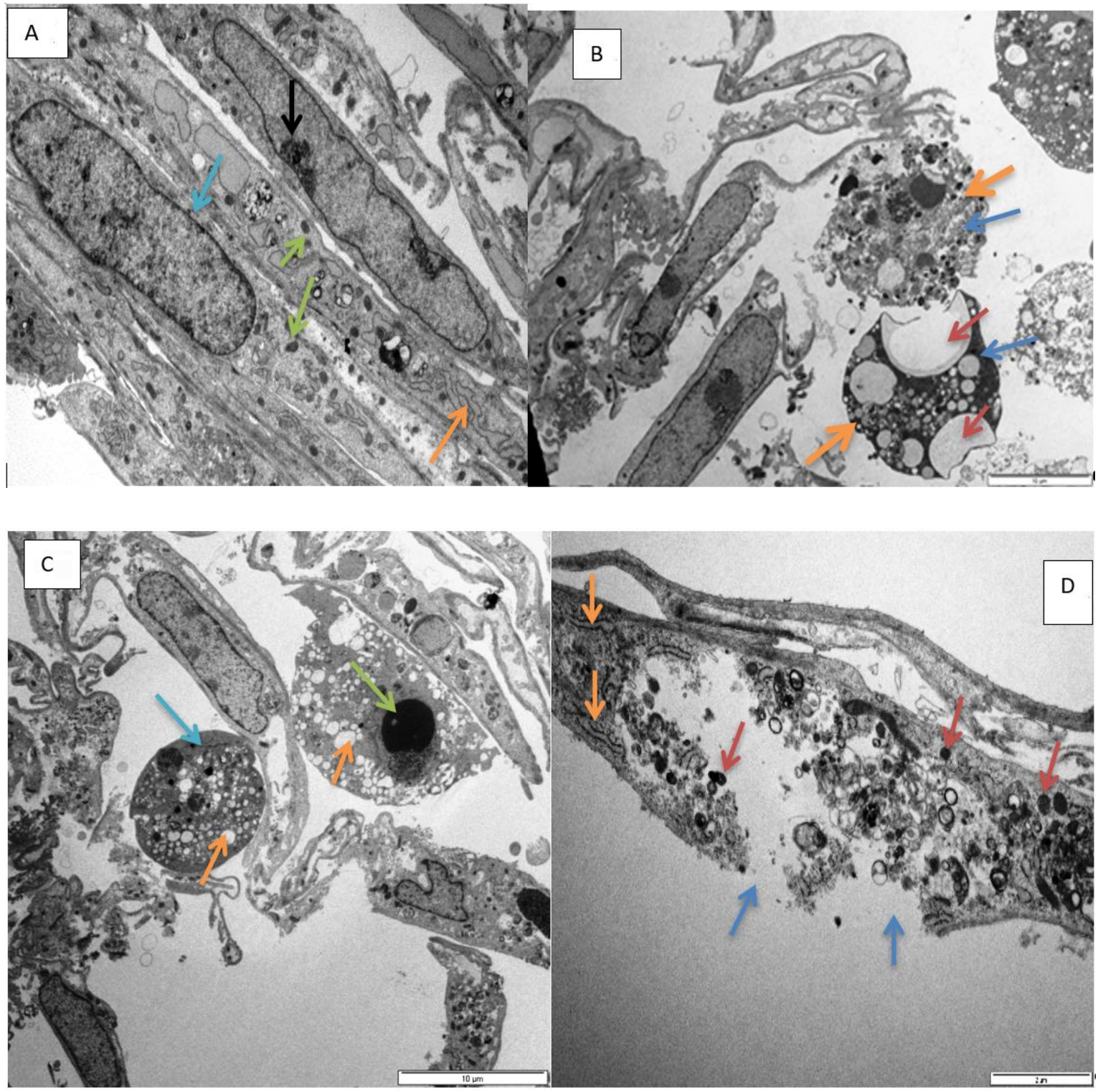

Figure 5. Cont. 


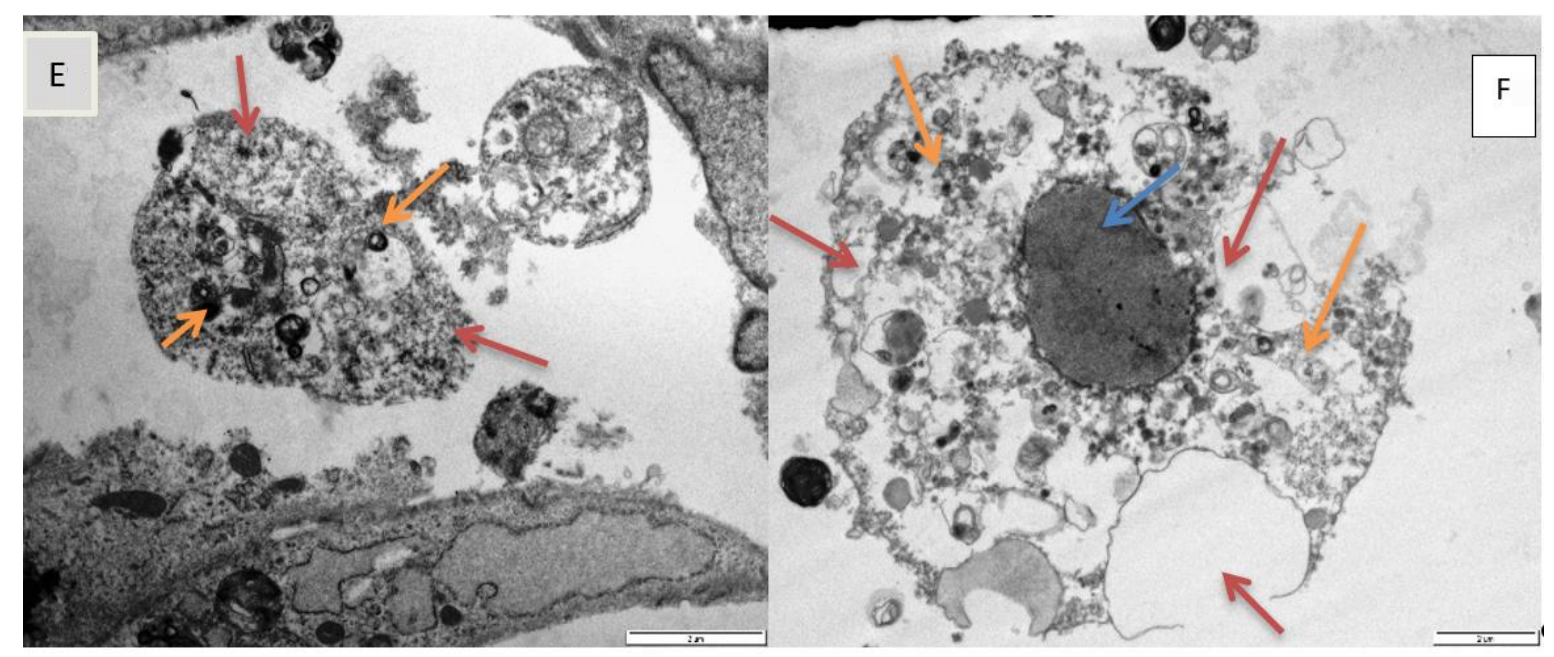

Figure 5. Transmission electron micrograph showing, (A). nucleus (blue arrow), mitochondria (green arrows), and endoplasmic reticulum (ER, orange arrow) in normal H9c2 cells (72 h control). Scale bar $5 \mu \mathrm{m}$. (B). Micrograph showing vacuolation (brown arrows), diffuse dissolution of the cytoplasm (blue arrows), spherical shaped cells (thick orange arrows) in H9c2 cells exposed to epoxyscillirosidine $(160 \mu \mathrm{M})$ after $24 \mathrm{~h}$. Scale bar $10 \mu \mathrm{m}$. (C). Micrograph showing karyolysis (green arrow), vacuolation (orange arrows) and diffuse dissolution of the cytoplasm and organelles (blue arrow) in H9c2 cells (200 $\mu \mathrm{M}, 24$ h). Scale bar $10 \mu \mathrm{m}$. (D). Micrograph showing damaged plasma membrane (blue arrows), numerous vesicles containing electron dense material (brown arrow) and ER (orange arrows) in H9c2 cells (120 $\mu \mathrm{M}, 48 \mathrm{~h})$. Scale bar $2 \mu \mathrm{m}$. (E). Micrograph showing diffuse dissolution of the cytoplasm (blue arrow) and vesicles containing electron dense material (orange arrows) in amoeboid mis-shaped H9c2 cells (40 $\mu \mathrm{M}, 72 \mathrm{~h}$ ). Scale bar $2 \mu \mathrm{m}$. (F). Micrograph showing karyolysis (blue arrow), vacuolation (brown arrows) and diffuse dissolution of the cytoplasm (orange arrows) in H9c2 cells (200 $\mu \mathrm{M}$, after 72 h). Scale bar $2 \mu \mathrm{m}$.

Furthermore, varying degree of karyolysis were observed in different exposures at higher doses (80-200 $\mu \mathrm{M})$ (Figure 5C,F). Further nuclear alterations, induced by epoxyscillirosidine exposure, were also observed. Chromatin condensation, a typical marker of apoptosis, was also observable in some cells, most likely as a result of normal physiological function, due to senescence and ageing in H9c2 cells, which may not be related to epoxyscillirosidine exposure (not shown).

The cell membrane was interrupted, with wide spaces of discontinuity at higher concentrations (120-200 $\mu \mathrm{M})$ at 48 (Figure 5D) and $72 \mathrm{~h}$ (not shown). Furthermore, increased cytosolic vacuoles were observed at these exposures (Figure 5F).

\section{Discussion}

This report describes the in vitro cytotoxic effect of epoxyscillirosidine on H9c2 cells. At 24, 48, and $72 \mathrm{~h}$ following exposure to epoxyscillirosidine, a dose and time dependent effect was observed. Interestingly, at low doses, epoxyscillirosidine stimulates cell viability. Weyermann et al., [11] reported increased values (above 100\%) for viability, using MTT assay at low doses following exposure to sodium azide in mouse fibroblasts L (tk-) cells. This observation could be explained by hormesis, whereby a stress agent that is injurious to a biological system at high doses, produces a stimulatory effect at low doses [12,13]. Thus, the agent causes low dose stimulation and high dose inhibition of the observed/measured end point. Several in vitro studies have reported hormesis in different compounds, including the cardiac glycoside ouabain [14-16]. There are two major mechanisms that have been explained. It has been postulated that hormesis occurs as a compensatory mechanism, following exposure to any stress agent, and the mechanism is similar regardless of the level of organization (i.e, cell, tissue, organ, or whole organism), the nature of the stress agent (i.e, chemical, physical, or biological) or the endpoint measured (viability, cell proliferation, or death). The two pathways 
reported to mediate hormesis, are the signaling and the receptor mediated pathways [16]. It was reported that hormesis causes an increase to a factor less than two, and a maximal increase of 30-60\% relative to control values [14]. The mechanism through which hormesis was mediated was, however, not investigated in this study. Ouabain, a cardenolide-type cardiac glycoside, was reported to induce hormesis through both receptor [17] and signaling pathway [18] systems.

The lowest viability was detected after $48 \mathrm{~h}$. At $24 \mathrm{~h}$, the time is probably too shorter to elicit a high toxic effect, resulting in higher viability relative to $48 \mathrm{~h}$. Pathological effects following exposure of cells to chemicals/stressors have been reported to be dose and time dependent in in vitro studies [19-22]. However, at $48 \mathrm{~h}$, more cells were damaged and hence the relatively lower viability. At $72 \mathrm{~h}$, the unaffected cells have likely proliferated, following $96 \mathrm{~h}$ of seeding. This may explain the reason why the viability at $72 \mathrm{~h}$ was higher than that at $48 \mathrm{~h}$.

The median lethal concentrations differed with exposure duration. At $72 \mathrm{~h}$, the $\mathrm{LC}_{50}$ was higher than at $48 \mathrm{~h}$, but lower than at $24 \mathrm{~h}$. This could be explained by the fact that, at $72 \mathrm{~h}$, the cells that were not affected by the toxin had proliferated and increased in number. Normally, H9c2 cells reach about $70-80 \%$ confluence $72-96 \mathrm{~h}$ following seeding. The values of $\mathrm{LC}_{50}$ have been reported to be influenced by exposure times according to the different experimental settings [23]. In contrast, in another study [24], the $\mathrm{EC}_{50}$ values reported for epoxyscillirosidine were much lower (41.39 \pm 4.37 , $25.42 \pm 3.73$ and $12.65 \pm 2.75 \mu \mathrm{M}$ for 24,48 and $72 \mathrm{~h}$ exposures, respectively). It should be noted that $\mathrm{LC}_{50}$ just like $\mathrm{LD}_{50}$ is not a biologic constant. In fact, $\mathrm{LC}_{50}$ values could be influenced by different factors depending on the experimental conditions [23].

The cytotoxicity, using the MTT and LDH assay, did not yield similar results. The LDH assay showed a higher degree of variability, while the MTT assay produced more consistent values. Bopp and Lettieri [25] had similarly reported higher intra- and inter-assay variabilities for LDH, compared to the MTT assay and two other fluorometric methods. Cytotoxicity as measured with the LDH assay produced higher values even at low doses (Figure 3), whereas low doses stimulated cell viability as determined by the MTT assay. This may be explained by the fact that the LDH assay measured all dead cells, including those that may have died physiologically. In addition, newly damaged cells retain residual mitochondrial dehydrogenase activity, which could contribute to the metabolism of MTT in non-viable cells [26]. On the other hand, cytotoxicity is not exactly the opposite of cell viability. A cell may be exposed to an injurious agent, without the cell dying, but only experiencing some compromise in cellular functions. Thus the term 'cell vitality' refers to the physiological capabilities of cells [27], a different phenomenon from viability. The MTT assay determines viability, which is a positive phenomenon in metabolically active cells [28]. Furthermore, at low doses, cell viability was stimulated (hormesis), and thus, the lowered cytotoxicity at lower doses, as captured by the MTT assay, was possibly due to metabolic activation, resulting in higher than expected values for viability. It was hypothesized that metabolic activation was responsible for the increased viability, due to chitosan/sulphated locust bean nano-particle exposure in Caco-2 cells, as revealed by MTT assay [29].

Electron microscopy has provided insight into the morphological alterations, caused by exposure to epoxyscillirosidine for 24,48 , and $72 \mathrm{~h}$. At the lowest dose evaluated ( $40 \mu \mathrm{M})$, no noteworthy ultrastructural alterations were observed. This is supported by the results of the MTT assay, where decreased viability only started manifesting from $60 \mu \mathrm{M}$ epoxyscillirosidine (at $24 \mathrm{~h}$ ). However, the highest dose $(200 \mu \mathrm{M})$ was characterized by numerous cytoplasmic vacuoles and significant nuclear alterations, which include chromatin dissolution (karyolysis, Figure 5C,F) and disruption of the nuclear envelope (Figure 5D). These features are typical of necrosis. The observed morphological changes at higher doses (160-200 $\mu \mathrm{M})$ are supported by the LDH assay findings, where LDH leakage through the damaged cell membranes, was demonstrated. Since the toxin interferes with and disrupts the sodium potassium ATPase on membrane of cells $[7,8]$, it causes disturbance in ionic homeostasis and subsequently necrosis. In corroboration of this study, Henn et al. [24] reported a 
mis-shaped nuclei and damage to the cell membrane in cells exposed to epoxyscillirosidine. The finding is consistent with myocardial necrosis observed microscopically in poisoned livestock [3].

In summary, following exposure of $\mathrm{H} 9 \mathrm{c} 2$ cells to different concentrations of epoxyscillirosidine, the dose-response relationship indicated a hormetic effect, where low doses stimulated cell viability. The median lethal concentration of epoxyscillirosidine in rat embryonic cardiomyocytes (H9c2) as calculated, varied with $24 \mathrm{~h}$ being the highest, followed by 72 and $48 \mathrm{~h}$ in that order. The $\mathrm{LC}_{50}$ was $382.68,132.28$, and $289.23 \mu \mathrm{M}$ for 24,48 , and $72 \mathrm{~h}$, respectively. Ultra-structural changes showed that the cause of $\mathrm{H} 9 \mathrm{c} 2$ cell death, subsequent to epoxyscillirosidine exposure, is necrosis. Increased cell membrane permeability and leakage of content, as expected with necrotic cells, was confirmed with the $\mathrm{LDH}$ release assay. Based on the findings from this study, the $\mathrm{H} 9 \mathrm{c} 2$ cell line is a suitable in vitro model to study the effect of epoxyscillirosidine and could be used to study similar compounds.

\section{Materials and Methods}

\subsection{Chemicals and Reagents}

Purified epoxyscillirosidine (isolated according to the method of Naudé and Potgieter [30]) was available in the plant toxin collection of the Department of Paraclinical Sciences, Faculty of Veterinary Science, University of Pretoria, and was stored in a dried form in a refrigerator at $4{ }^{\circ} \mathrm{C}$. Dimethyl sulphoxide (DMSO, cat. no: SAAR1865000LP) and Triton X-100 were obtained from Merck (Darmstadt, Germany). Trypsin-EDTA (cat no: BE17-16IF) and L-glutamine (cat no: BE-17-605E) were acquired from Lonza (Verviers, Belgium). The LDH assay kit (CytoTox-ONE ${ }^{\mathrm{TM}}$, cat. no: G7890) was purchased from Promega Corp., USA. Dulbecco's Modified Eagle's Medium (DMEM, cat. no: D6546), phosphate buffered saline (PBS, cat. no: P4417), penicillin-streptomycin (cat. no: P4333), MTT (thiazolyl blue tetrazolium bromide) reagent (cat. no: M5655), and trypan blue (cat. no: T6146) were from Sigma-Aldrich (Darmstadt, Germany). Foetal bovine serum (cat. no: 10499-044, Gibco) was from Life Technologies (Grand Island, NY, USA).

\subsection{Cell Culture}

Rat embryonic cardiomyocytes (H9c2 (2-1) cells) [9] were purchased from the American Type Culture Collection (ATCC) (Manassas, Virginia, USA, cat no: CRL-1446 ${ }^{\mathrm{TM}}$ ). The cells were cultured in DMEM supplemented with $10 \%$ foetal bovine serum, $4 \mathrm{mM} \mathrm{L}$ glutamine and penicillin-streptomycin $(100 \mathrm{U} / \mathrm{mL})$ in $75 \mathrm{~cm}^{2}$ tissue culture flasks. Cells were maintained in a humidified incubator (HeraCELL $150^{\mathrm{R}}$, Thermo-Electron Corporation, Waltham, MA, USA) in a $95 \%$ air $5 \% \mathrm{CO}_{2}$ environment at $37^{\circ} \mathrm{C}$. Medium was changed every $3-4$ days, while the cells were sub-cultured after attaining about $70-80 \%$ confluency. Cells were detached using trypsin-EDTA. Cells were seeded for cytotoxicity and ultrastructural studies in 96-well microtitre plates, and 12-well plates, respectively.

\subsection{Cytotoxicity Studies}

The cells were detached from the cultivation flasks, using trypsin-EDTA, and counted with a hemocytometer with the aid of trypan blue exclusion to determine viability. Three 96-well plates were seeded with $1 \times 10^{4}$ cells per well (final volume $200 \mu \mathrm{L}$ per well). A triplicate of wells in each plate contained only medium, with no cells which served as blank. The plates were incubated for 24 hours to allow for cell attachment and recovery. Thereafter, 10, 20, 40, 60, 80, 120, 160, and $200 \mu \mathrm{M}$ concentrations of epoxyscillirosidine were added to the wells in triplicate. Cells cultured in growth medium only, representing $100 \%$ viability were used as negative control in all experiments. In the $\mathrm{LDH}$ release assay, Triton X-100 was added to separate cells in triplicate as positive controls. The three plates were incubated for 24,48 , and $72 \mathrm{~h}$, respectively, before the evaluation of cell viability and cytotoxicity using MTT, and LDH assays, respectively. The assays were validated and optimized before adoption in each case. The doses selected were identified following a preliminary dose finding study. The experiments were repeated three times, at weekly intervals. 


\subsubsection{Evaluation of Cell Viability}

Cell viability, following exposure of $\mathrm{H} 9 \mathrm{c} 2$ cells to varying concentrations of epoxyscillirosidine, was determined using the MTT assay [28]. This is a quantitative colorimetric assay, that spectrophotometrically measures the amount of purple formazan crystals, formed by dehydrogenases in living viable cells from the yellow tetrazolium salt MTT. In brief, the three plates were treated after 24, 48, and $72 \mathrm{~h}$, respectively, as follows: $100 \mu \mathrm{L}$ of the medium was transferred to the LDH assay plate and the remaining medium decanted and cells washed with PBS $(200 \mu \mathrm{L}$ per well), followed by the addition of fresh DMEM (200 $\mu \mathrm{L}$ per well). Thereafter, $20 \mu \mathrm{L}$ MTT reagent was added serially into all wells. The plates were incubated for $2 \mathrm{~h}$. The medium, containing MTT reagent, was decanted, followed by the addition of $100 \mu \mathrm{L}$ DMSO and shaking on a microplate shaker for $5 \mathrm{~min}$ to dissolve formed formazan. The absorbance was read in a multi-reader (Synergy HT, BioTek ${ }^{\mathrm{R}}$ EL808, Winooski, VT, USA) using the Gen 5 protocol at $570 \mathrm{~nm}$ versus $630 \mathrm{~nm}$. Percentage cell survival was calculated using the formula:

\section{Cell viability $(\%)=($ Absorbance of epoxyscillirosidine/Absorbance of cells only $) \times 100$}

The median lethal concentration $\left(\mathrm{LC}_{50}\right)$ of epoxyscillirosidine was calculated using the straight line equation of the log dose-response curve of cytotoxicity against concentration.

\subsubsection{Cytotoxicity Assay Using LDH Release}

Cytotoxicity in H9c2 cells exposed to epoxyscillirosidine was evaluated using the LDH assay, with the aid of a commercial kit CytoTox-ONE ${ }^{\mathrm{TM}}$. This is a fluorometric method that estimates the number of dead cells present in multi-well plates. The CytoTox-ONE ${ }^{\mathrm{TM}}$ assay rapidly measures the release of LDH from cells with a damaged membrane. LDH released into the culture medium is measured with a 10 min coupled enzymatic assay, that results in the conversion of resazurin into a fluorescent resorufin product. The amount of fluorescence produced is proportional to the number of lysed cells. The assay was carried out according to the manufacturer's instructions. Aliquots $(100 \mu \mathrm{L})$ of medium, from all wells in the plate seeded with $\mathrm{H} 9 \mathrm{c} 2$ cells, were transferred into a black Nunc 96 well plate. Reconstituted LDH substrate mixture (100 $\mu \mathrm{L}$ each) was added to the wells in the black plate, which was wrapped and shaken for $10 \mathrm{~min}$. Stop solution was added and fluorescence was read at an excitation wavelength of $560 \mathrm{~nm}$ and an emission wavelength of $590 \mathrm{~nm}$ and at a fluorescence sensitivity setting of 40, in a Synergy HT, BioTek ${ }^{\mathrm{R}}$ EL808 (Winooski, VT, USA) multi-reader. Per-cent cytotoxicity was calculated using the formula:

$$
\text { Cytotoxicity }(\%)=(\text { experimental }- \text { blank }) /(\text { Triton } X-\text { blank }) \times 100
$$

\subsection{Evaluation of Ultrastructural Changes Using TEM}

Three 12-well plates, in which coverslips were placed in each well, were seeded with $1 \times 10^{5}$ cells per well (final volume $2 \mathrm{~mL}$ per well). The plates were incubated for $24 \mathrm{~h}$ for the cells to recover and stabilize. Thereafter, 40, 80, 120, 160, and $200 \mu \mathrm{M}$ concentrations of epoxyscillirosidine were added to the wells in duplicate. Untreated cells were used as control. The three plates were incubated for 24,48 , and $72 \mathrm{~h}$, respectively, before the cells were further processed for TEM.

The culture medium was carefully removed from the wells and replaced with $2 \mathrm{~mL}$ of $2.5 \%$ glutaraldehyde in $0.075 \mathrm{M}$ sodium phosphate $\left(\mathrm{NaPO}_{4}\right)$ buffer $(\mathrm{pH} 7.4)$ and left for $1 \mathrm{~h}$. The coverslips were removed and placed in a separate holder. The cells were scraped off from the culture coverslips, transferred to $2 \mathrm{~mL}$ Eppendorf tubes, and centrifuged at $2356 \mathrm{~g}$ to form pellets. These, as well as the coverslips, were then rinsed 3 times in $0.075 \mathrm{M}$ phosphate buffer for $10 \mathrm{~min}$, and post-fixed for $1 \mathrm{~h}$ with $1 \%$ osmium tetroxide $\left(\mathrm{OsO}_{4}\right)$. Samples were then rinsed again in $0.075 \mathrm{M}$ phosphate buffer for $10 \mathrm{~min}$ and then dehydrated serially in 30,50,70,90\% and three times with 100\% ethanol. The samples were embedded in TAAB 812 epoxy resin [31], followed by ultra-microtome sectioning. The sections were 
contrasted with a $2 \%$ aqueous solution of uranyl acetate for $10 \mathrm{~min}$ and lead citrate [32] for $2 \mathrm{~min}$ and examined with a Philips CM10 (Philips Electron Optics, Eindhoven, The Netherlands) TEM

\subsection{Data Analysis}

Data were analysed using GraphPad Prism 7 for windows (version 7.03, GraphPad Prism Software Inc., La Jolla, CA, USA). Values were expressed as percentage of untreated control cells. Student's $t$-test or ANOVA was used to evaluate statistical difference for paired, or multiple comparison between groups respectively. Statistical significance was set at $p<0.05$.

Author Contributions: Conceptualization, H.I.I., J.E.C. and C.J.B.; data curation, H.I.I., G.C.H.F., and J.E.C.; funding acquisition, C.J.B.; investigation, H.I.I., G.C.H.F., J.E.C., and C.J.B.; methodology, H.I.I., G.C.H.F., and J.E.C.; project administration, C.J.B.; resources, C.J.B.; supervision, J.E.C. and C.J.B.; validation, H.I.I. and G.C.H.F.; writing — original draft, H.I.I.; writing—-review and editing, G.C.H.F., J.E.C., and C.J.B.

Funding: This work was supported by the Tshwane Animal Health Innovation Cluster (Grant number TAHC 12-00031).

Acknowledgments: The authors would like to express their gratitude to Chris van der Merwe who performed the TEM.

Conflicts of Interest: The authors declare no conflict of interest.

\section{References}

1. Kellerman, T.S.; Naudé, T.W.; Fourie, N. The distribution, diagnoses and estimated economic impact of plant poisonings and mycotoxicoses in South Africa. Onderstepoort J. Vet. Res. 1996, 63, 65-90. [PubMed]

2. Naudé, T.W. The occurrence and significance of South African cardiac glycosides. J. South Afr. Biol. Soc. 1977, 18, 7-20.

3. Kellerman, T.S.; Coetzer, J.A.W.; Naudé, T.W.; Botha, C.J. Plant Poisonings and Mycotoxicoses of Livestock in Southern Africa, 2nd ed.; Oxford University Press: Cape Town, South Africa, 2005; pp. 115-146.

4. Enslin, P.R.; Naudé, T.W.; Potgieter, D.J.J.; Van Wyk, A.J. ' $1 \alpha, 2 \alpha$-Epoxyscillirosidine, the main toxic principle of Homeria glauca (Wood and Evans) N.E. Br'. Tetrahedron 1966, 22, 3213-3220. [CrossRef]

5. Snyman, L.D.; Kellerman, T.S.; Schultz, R.A.; Joubert, J.P.J.; Basson, K.M.; Labuschagne, L. Conditioned feed aversion as a means of preventing intake of yellow tulp (Homeria pallida) by livestock. In Poisonous Plants and Related Toxins; Acamovic, T., Steward, C.S., Pennycott, T.W., Eds.; CABI Publishing: Wallingford, UK, 2004; pp. 531-539.

6. Snyman, L.D.; Schultz, R.A.; Joubert, J.P.J.; Botha, C.J.; Labuschagne, L. Evaluation of activated charcoal as treatment for yellow tulp poisoning in cattle. J. South Afr. Vet. Assoc. 2009, 80, 274-275.

7. Steyn, P.S.; van Heerden, F.R. Bufadienolides of plant and animal origin. Nat. Prod. Rep. 1998, 15, 397-413. [CrossRef] [PubMed]

8. Kamboj, A.; Rathour, A.; Kaur, M. Bufadienolides and their medicinal utility: A review. Int. J. Pharm. Pharm. Sci. 2013, 5, 20-27.

9. Kimes, B.W.; Brandt, B.L. Properties of a clonal muscle cell line from rat heart. Exp. Cell Res. 1976, 98, 367-381. [CrossRef]

10. Witek, P.; Korga, A.; Burdan, F.; Ostrowska, M.; Nosowska, B.; Iwan, M.; Dudka, J. The effect of a number of $\mathrm{H} 9 \mathrm{C} 2$ rat cardiomyocytes passage on repeatability of cytotoxicity study results. Cytotechnology 2016, 68, 2407-2415. [CrossRef]

11. Weyermann, J.; Lochmann, D.; Zimmer, A. A practical note on the use of cytotoxicity assays. Int. J. Pharm. 2005, 288, 369-376. [CrossRef]

12. Calabrese, E.J;; Baldwin, L.A. Hormesis: A generalizable and unifying hypothesis. Crit. Rev. Toxicol. 2008, 31, 353-424. [CrossRef] [PubMed]

13. Calabrese, E.J. Biphasic dose responses in biology, toxicology and medicine: Accounting for their generalizability and quantitative features. Environ. Pollut. 2013, 182, 452-460. [CrossRef]

14. Calabrese, E.J.; Baldwin, L.A.; Holland, C.D. Hormesis: A highly generalizable and reproducible phenomenon with important implications for risk assessment. Risk Anal. 1999, 19, 261-281. [CrossRef]

15. Calabrese, E.J.; Baldwin, L.A. The frequency of U-shaped dose responses in the toxicological literature. Toxicol. Sci. 2001, 62, 330-338. [CrossRef] 
16. Calabrese, E.J. Hormetic mechanisms. Crit. Rev. Toxicol. 2013, 43, 580-606. [CrossRef]

17. Tian, J.; Li, X.; Liang, M.; Liu, L.; Xie, J.X.; Ye, Q.; Kometiani, P.; Tillekeratne, M.; Jin, R.; Xie, Z. Changes in sodium pump expression dictate the effects of ouabain on cell growth. J. Biol. Chem. 2009, 284, 14921-14929. [CrossRef]

18. Chueh, S.C.; Guh, J.H.; Chen, J.; Lai, M.K.; Teng, C.M. Dual effects of ouabain on the regulation of proliferation and apoptosis in human prostatic smooth muscle cells. J. Urol. 2001, 166, 347-353. [CrossRef]

19. Al-Ghamdi, S.S. Time and dose dependent study of doxorubicin induced du- 145 cytotoxicity. Drug Metab. Lett. 2008, 2, 47-50. [CrossRef] [PubMed]

20. Ellis, C.E.; Naicker, D.; Basson, K.M.; Botha, C.J.; Meintjes, R.A.; Schultz, R.A. Cytotoxicity and ultrastructural changes in H9c2(2-1) cells treated with pavetamine, a novel polyamine. Toxicon 2010, 55, 12-19. [CrossRef] [PubMed]

21. Neiva, L.B.M.; Fonseca, C.D.; Watanabe, M.; Vattimo, M.F.F. Polymyxin B: Dose and time dependent nephrotoxicity effect in vitro. Acta Paul Enferm. 2013, 26, 57-62. [CrossRef]

22. Souza, T.M.; Kleinjans, J.C.S.; Jennen, D.G.J. Dose and time dependencies in stress pathway responses during chemical exposure: Novel insights from gene regulatory networks. Front. Genet. 2017, 8, 142. [CrossRef]

23. Zhang, M.; Aguilera, D.; Das, C.; Vasquez, H.; Zage, P.; Gopalakrishnan, V.; Wolff, J. Measuring cytotoxicity: A new perspective on LC50. Anticancer Res. 2007, 27, 35-38.

24. Henn, D.; Venter, A.; Botha, C. In vitro cytotoxicity induced by the bufadienolides $1 \alpha, 2 \alpha$-epoxyscillirosidine and lanceotoxin B on rat myocardial and mouse neuroblastoma cell lines. Toxins 2019, 11, 14. [CrossRef]

25. Bopp, S.K.; Lettieri, T. Comparison of four different colorimetric and fluorometric cytotoxicity assays in a zebrafish liver cell line. BMC Pharmacol. 2008, 8, 8. [CrossRef]

26. Otto, M.; Hansen, S.H.; Dalgaard, L.; Dubois, J.; Badolo, L. Development of an in vitro assay for the investigation of metabolism-induced drug hepatotoxicity. Cell Biol. Toxicol. 2008, 24, 87-99. [CrossRef]

27. Kwolek-Mirek, M.; Zadrag-Tecza, R. Comparison of methods used for assessing the viability and vitality of yeast cells. FEMS Yeast Res. 2014, 14, 1068-1079. [CrossRef]

28. Mosmann, T. Rapid colorimetric assay for cellular growth and survival: Application to proliferation and cytotoxicity assays. J. Immun. Methods 1983, 65, 55-63. [CrossRef]

29. Braz, L.; Grenha, A.; Ferreira, D.; Ana, M.; Rosa da Costa, A.M.; Gamazo, C.; Sarmento, B. Chitosan/sulfated locust bean gum nanoparticles: In vitro and in vivo evaluation towards an application in oral immunization. Int. J. Biol. Macromol. 2017, 96, 786-797. [CrossRef]

30. Naudé, T.W.; Potgieter, D.J.J. A preliminary note on the isolation and pharmacological actions of the toxic principles of Homeria glauca (W \& E). N.E. Br. J. South Afr. Vet. Assoc. 1966, 37, 73-75.

31. Luft, J.H. Improvements in epoxy resin embedding methods. J. Biophys. Biochem. Cytol. 1961, 9, 409-414. [CrossRef]

32. Reynolds, E.S. The use of lead citrate at high $\mathrm{pH}$ as an electron-opaque stain in electron microscopy. J. Cell Biol. 1963, 17, 208-212. [CrossRef]

(C) 2019 by the authors. Licensee MDPI, Basel, Switzerland. This article is an open access article distributed under the terms and conditions of the Creative Commons Attribution (CC BY) license (http://creativecommons.org/licenses/by/4.0/). 